\title{
Role of Lokadalaths in Indian Judiciary as a Dispute Resolution Mechanism In Order To Achieve Social Justice-A Study
}

\author{
T. S. Shyam Prasad., \\ M.Com. M.A., M.Phil. LL.B., NET., \\ Lecturer in Political Science K.H.Government Degree College DHARMAVARAM-515671 \\ Anantapur District Andhrapradesh State
}

\begin{abstract}
In a country which is geographically large and overpopulated with a system of plurality of laws, low literacy levels and abject poverty, anything good or bad can happen and mostly does happen in one corner or the other of the country. Society is filled with tensions and these tensions give rise to disputes and these disputes have to be resolved expeditiously before they assume ugly proportions. In a society governed by the Rule of Law, it is essential that its members respect and obey the laws. This can be possible only when the victim of the infraction of the law receives the protection of the law for otherwise it is but natural that the victim will try to evolve his own methodology of protection which may include resorting to violence. No just government can expect adherence ti its laws from those to whom it cannot extend the law's protection. Therefore, when members of a civilized society shun uncivilized modes for dispute resolution and agree to have their disputes resolved in an orderly manner through a mechanism offered by the State, there is an implied understanding that the mechanism will be not only independent and impartial but will also be in a position to resolve the dispute within a reasonable time. The judiciary of our country has been assigned the role of final arbiter and therefore, it is charged with the duty to resolve the disputes brought before it with dispatch and extend protection of the laws to law-abiding citizens. To realize the constitutional objective, laws introducing large scale reforms had to be enacted from time to time which were challenged by the vested groups as ultra virus the fundamental rights enshrined in Part III of the Constitution. Besides, the State extended its activities to the industrial and commercial fields through statutory corporations and public-sector undertakings. With the expansion of the state's activities in the field of trade and commerce, a good number of disputes arose between citizens and Government which were carried to courts for adjudication. All these factors generated a flood of litigation, natural commitment of development, which the courts were neither ready nor equipped to tackle. A look at the statistical data of the last twenty five years unfolds the enormity of the problem. The only way in which easy access to justice can be provided to them is by developing an alternative which would carry justice to their door steps. This has been possible through Lok-adalaths and Para Legal and Legal Literacy Camps which offer an informal system for on the spot resolution of disputes, prevent disruption of local unity and secure social justice which is in tune with the life style and culture of village-folk. Justice rendered at such lok-adalaths in the presence and hearing of others from the locality or village is more satisfying and nearer to the truth. With the heavy case-load in the traditional courts and time consuming process through which litigation must pass, looking for alternative modes for disposal of cases is compelling necessary. The purpose of this present article is to share the experience, identify the drawbacks or short comings of the present lok-adalath system with a view to making it more and more people-oriented.
\end{abstract}

Key Words: Alternative Dispute Resolution, constitution, counseling, conciliation, docket-explosion, legal services, litigation, magnacarta, social-justice

\section{Introduction:}

Justice is the most important component of any civilized society and the role of judiciary becomes significant in dispensing justice. The number of pending cases before the court has shown a tremendous increase which has led to pendency and delay in the disposition of the case. In such a scenario, access to justice through Alternative Dispute Resolution (Hereinafter ADR) becomes important. Lok- Adalat is one of the fine and familiar mechanism of ADR which has been playing an important role in the settlement of disputes. The institution of Lok-Adalat has deep roots in Indian legal history and has played a significant role in providing justice to the Indian society. Lok-Adalat acquired its statutory status from The Legal Services Authority Act, 1987 and constitutional mandate as provided in Article39A of the Constitution. The main objective of LokAdalat is to provide free legal services to the weaker section of the society and ensure the opportunity for securing justice is not denied.3Though through Lok -Adalat, disputes can be settled in a simpler, quicker and cost-effective way but dispute cannot be settled if both parties do not give their consent for settlement. 
In a country which is geographically large and overpopulated with a system of plurality of laws, low literacy levels and abject poverty, anything good or bad can happen and mostly does happen in one corner or the other of the country. Society is filled with tensions and these tensions give rise to disputes and these disputes have to be resolved expeditiously before they assume ugly proportions. In a society governed by the Rule of Law, it is essential that its members respect and obey the laws. This can be possible only when the victim of the infraction of the law receives the protection of the law for otherwise it is but natural that the victim will try to evolve his own methodology of protection which may include resorting to violence. No just government can expect adherence ti its laws from those to whom it cannot extend the law's protection. Therefore, when members of a civilized society shun uncivilized modes for dispute resolution and agree to have their disputes resolved in an orderly manner through a mechanism offered by the State, there is an implied understanding that the mechanism will be not only independent and impartial but will also be in a position to resolve the dispute within a reasonable time. The judiciary of our country has been assigned the role of final arbiter and therefore, it is charged with the duty to resolve the disputes brought before it with dispatch and extend protection of the laws to law-abiding citizens. It is ,therefore, essential that every citizen who seeks to enforce his legal right or who seeks the protection of the law against the violation of his right must have access to the dispute resolution mechanism for otherwise he will resort to other means to enforce or protect his legal right. Access to justice, is, therefore, essential for orderly governance of the country. The concept that every individual should have equal access to justice is as old as the Magna Carta which pledged "To no one will we sell, to no one will we refuse or delay right or justice". And the right to counsel was statutorily recognized by Henry VII in 1495, when it ordained "The justice--------shall assign to the ------poor person or persons counsel learned, by their discretions which shall give their counsel, nothing taking for the same". The concept of free legal aid enshrined in Article 39A of our constitution is, therefore, an old one.

\section{Historical Background For Inception Of The Concept Of Lok-Adalath:}

India is an ancient civilization more than 3000 years old. In the history past, its judicial system was governed by (i) the Dharma Shastras (ii) the Srutis and the Smrities and (iii) the Arthashastra. The ancient law givers and jurists like Manu, Yagnavalkya etc., defined Dharma, clarified the notions of justice and enumerated the principles on which courts were expected to render justice. It is for this reason that India claims to have the oldest judiciary in the world. In Medieval India particularly during the Muslim rule, the Indian Judicial System underwent a change. Laws were replaced and codified. The Judicial System was manned by men of learning who maintained very high standards of honesty, integrity and morality. Great emphasis was laid on purity in the administration of justice.

Then came the East India Company and latter the British rule. During the days of the East India Company, courts of limited jurisdiction were set up to judge all those living under the banner of the company by the laws of England. But this was a purely executive arrangement. Thereafter a new judicial system was introduced initially in the Presidency Towns of Bombay, Calcutta and Madras. In course of time, the courts so constituted were replaced by the establishment of Supreme Courts in the aforesaid towns. Later in 1862 High Courts were established in the country under the High CourtsAct,1861. The creation of the Federal Court for the country in 1937 introduced a sweeping change. The Federal Court was invested with the jurisdiction to interpret the provisions of the Government of India Act, 1935 and thus resolve important constitutional issues between the citizens and the Government.

India is a vast country with a rich heritage. The way of life of the people of this country has been religion-oriented. Notwithstanding the much abhorred caste-system, the religion-oriented culture had introduced a sense of contentment, tolerance and fraternity among the people and struggle for existence was at a low level. Consequently the disputes were far and few. Life was by and large spiritual, less complex and based on theory of co-existence treating the entire humanity as one family with the creator at its head. The culture of tolerance enabled several races to converge in this sub-continent e.g. the Aryans from the North-East, the Mongolians from the East, the Dravidians from the South and the Semitics from the West. They brought with them their own cultures, languages, religions and customs. The philosophy of accommodation and tolerance preached by great saints like Buddha, Mahavir, Guru Nanak and the Sufis and benevolent rulers like Ashoka, Akbar and others helped India to emerge as the world's most heterogeneous society. Thus, although on the surface, there appeared great diversities the culture of treating the entire humanity as a large family developed a feeling of fraternity and inculcated the culture of accommodation and tolerance. This had by and large reduced tension and made the struggle for existence relatively less competitive and therefore less litigious. Even where disputes arose, the vast majority of such disputes were resolved by the intervention of respected elders which later gave rise to the system of panchas meaning a Council of the chosen five. Since decision making or rendition of justice was considered a divine function, the verdict given by the Panchas was generally accepted as the Panchas were held in high esteem, and refusal to accept their verdict was considered an interference with divine will and, therefore, highly immoral and unethical. The socio-religious sanction which attached to the decision rendered by Panchas 
gives rise to a dispute resolution mechanism which in course of time came to be formalized as NYAYA PANCHAYATS. Though between the $11^{\text {th }}$ and $18^{\text {th }}$ century, the Moghul rule spread and prevailed over a large part of the country and dispensation of justice was through the Kazi, the pre-litigation settlement of disputes through panchas remained by and large unaffected. This indigenous system had two great virtues namely, it was inexpensive and quick and acceptable to the people notwithstanding certain aberrations which had crept in and manifested themselves over a period of time. The East India Company also did not try to dislocate the system but with the gradual introduction of the English Common Law notions and the establishment of the adjudicatory courts on the British model and the Nyaya Panchayats and Kazi courts are faded away. It is thus obvious that while the Muslim rulers were indigenous, the British imported their judicial system and thus came into existence the present day Anglo-Saxon system.

\section{Causes And Factors Responsible In The System For Justice Delayed:}

\section{(A) Docket Explosion:}

Before India attained Independence, the volume of litigation was not large as the litigation between the citizens and the Government was limited. On realizing the political goal of independence, the first task our leaders were to transform the society into an egalitarian one. To realize the constitutional objective, laws introducing large scale reforms had to be enacted from time to time which were challenged by the vested groups as ultra virus the fundamental rights enshrined in Part III of the Constitution. Besides, the State extended its activities to the industrial and commercial fields through statutory corporations and public-sector undertakings. With the expansion of the state's activities in the field of trade and commerce, a good number of disputes arose between citizens and Government which were carried to courts for adjudication. All these factors generated a flood of litigation, natural commitment of development, which the courts were neither ready nor equipped to tackle. A look at the statistical data of the last twenty five years unfolds the enormity of the problem.

\section{Statement Showing The Cases Pending Both Civil And Criminal Cases Before The High Courts As On} 31-12-2013.

\begin{tabular}{|c|c|c|c|}
\hline Name of the High Court & Civil Cases & Criminal Cases & Total Cases \\
\hline Allahabad & $6,95,431$ & $3,47,967$ & $10,43,398$ \\
\hline Andhrapradesh & $2,01,425$ & 31,034 & $2,32,459$ \\
\hline Mumbai & 299,931 & 49,906 & 349,837 \\
\hline Kolkata & $2,30,317$ & 49,689 & $2,80,006$ \\
\hline Delhi & 49,000 & 15,652 & 64,652 \\
\hline Gujarat & 60,131 & 31,822 & 91,953 \\
\hline Gouhati & 33,534 & 7,378 & 40,912 \\
\hline Himachalpradesh & 54,015 & 6,058 & 60,073 \\
\hline Jammu\& Kashmir & 87,794 & 5,244 & 93,038 \\
\hline Karnataka & $1,79,379$ & 17,593 & $1,96,792$ \\
\hline Kerala & 99,573 & 32,586 & 132,159 \\
\hline Madras & $4,90,383$ & 67,096 & $5,57,479$ \\
\hline Madhyapradesh & $1,74,665$ & 86,946 & $2,61,611$ \\
\hline Orissa & $1,68,794$ & 38,028 & $2,06,822$ \\
\hline Patna & 79,896 & 52,259 & 132,155 \\
\hline Punjab \&Haryana & $2,00,349$ & 62,211 & $2,62,560$ \\
\hline Rajasthan & $2,44,020$ & 63,620 & $3,07,640$ \\
\hline Sikkim & 95 & 25 & 120 \\
\hline Uttatakhand & 15,269 & 5,417 & 20,686 \\
\hline Chattishgarh & 27,146 & 16,993 & 44,139 \\
\hline Jharkhand & 38,001 & 34,957 & 72,958 \\
\hline Tripura & 4,743 & 1,091 & 5,834 \\
\hline Manipur & 3,761 & 92 & 3,853 \\
\hline Meghalaya & 1,115 & 74 & 1,189 \\
\hline
\end{tabular}

Table :A

Source: Eenadu Telugu Daily dated:11/09/2014 at p.4 
Let us observe the above statistical information with regard to pendency of both civil and criminal cases before the High Courts as on 31-12-2013 and 34,38,967 Civil Cases and 10,23,738 Criminal Cases to the tune of total $44,62,705$ cases are pending.

(B) Vacancies In Higher Judicial Services:

Statement showing the Approved strength, Working Strength and Vacancies of Judges in the Supreme Court of India and the High Courts

\begin{tabular}{|c|c|c|c|c|c|c|c|c|c|c|}
\hline $\begin{array}{l}\text { Sl. } \\
\text { No. }\end{array}$ & Name of the Court & \multirow{2}{*}{\multicolumn{3}{|c|}{ Approved Strength }} & \multirow{2}{*}{\multicolumn{3}{|c|}{ Working Strength }} & \multicolumn{3}{|c|}{$\begin{array}{l}\text { Vacancies as per } \\
\text { Approved Strength }\end{array}$} \\
\hline A. & Supreme Court of India & & & & & & & & 05 & \\
\hline B. & High Court & Pmt & Addl. & Total & Pmt. & Addl. & Total & Pmt & Addl. & Total \\
\hline 1 & Allahabad & 76 & 84 & 160 & 71 & 17 & 88 & 05 & 67 & 72 \\
\hline 2 & $\begin{array}{l}\text { Telangana \& } \\
\text { Andhra Pradesh }\end{array}$ & 33 & 16 & 49 & 16 & 15 & 31 & 17 & 01 & 18 \\
\hline 3 & Bombay & 48 & 27 & 75 & 41 & 23 & 64 & 07 & 04 & 11 \\
\hline 4 & Calcutta & 45 & 13 & 58 & 27 & 13 & 40 & 18 & 0 & 18 \\
\hline 5 & Chhattisgarh & 06 & 12 & 18 & 04 & 08 & 12 & 02 & 04 & 06 \\
\hline 6 & Delhi & 45 & 15 & 60 & 26 & 11 & 37 & 19 & 04 & 23 \\
\hline 7 & Gauhati & 17 & 07 & 24 & 10 & 03 & 13 & 07 & 04 & 11 \\
\hline 8 & Gujarat & 29 & 13 & 42 & 27 & 04 & 31 & 02 & 09 & 11 \\
\hline 9 & Himachal Pradesh & 10 & 03 & 13 & 05 & 03 & 08 & 05 & 0 & 05 \\
\hline 10 & Jammu \& Kashmir & 13 & 04 & 17 & 08 & 02 & 10 & 05 & 02 & 07 \\
\hline 11 & Jharkhand & 10 & 10 & 20 & 09 & 01 & 10 & 01 & 09 & 10 \\
\hline 12 & Kamataka & 33 & 17 & 50 & 28 & 05 & 33 & 05 & 12 & 17 \\
\hline 13 & Kerala & 27 & 11 & 38 & 23 & 09 & 32 & 04 & 02 & 06 \\
\hline 14 & Madhya Pradesh & 40 & 13 & 53 & 23 & 09 & 32 & 17 & 04 & 21 \\
\hline 15 & Madras & 45 & 15 & 60 & 37 & 08 & 45 & 08 & 07 & 15 \\
\hline 16 & Manipur & 04 & 0 & 04 & 02 & 0 & 02 & 02 & 0 & 02 \\
\hline 17 & Meghalaya & 03 & 0 & 03 & 03 & 0 & 03 & 0 & 0 & 0 \\
\hline 18 & Orissa & 17 & 05 & 22 & 17 & 03 & 20 & 0 & 02 & 02 \\
\hline 19 & Patna & 29 & 14 & 43 & 27 & 07 & 34 & 02 & 07 & 09 \\
\hline 20 & Punjab\& Haryana & 64 & 21 & 85 & 32 & 14 & 46 & 32 & 07 & 39 \\
\hline 21 & Rajasthan & 32 & 08 & 40 & 18 & 09 & 27 & 14 & -01 & 13 \\
\hline 22 & Sikkim & 03 & 0 & 03 & 03 & 0 & 03 & 0 & 0 & 0 \\
\hline 23 & Tripura & 04 & 0 & 04 & 04 & 0 & 04 & 0 & 0 & 0 \\
\hline 24 & Uttarakhand & 09 & 0 & 09 & 06 & 0 & 06 & 03 & 0 & 03 \\
\hline & Total & 642 & 308 & 950 & 467 & 164 & 631 & 175 & 144 & 319 \\
\hline
\end{tabular}

Table: B

Source: The Law Commission Report No: 245

Let us examine the population figures of the country. At the first census held in 1951,the population of the country was estimated to be 361 million. The 1991 census put the figure at 389 million which has now gone up to 875 million. The total number of lawyers is stated to be 0.34 million i.e. $0.04 \%$ to the total population. The $120^{\text {th }}$ report of the Law Commission (1987) dealt with the question of Manpower planning in the judiciary. Pointing out that the judiciary was understaffed during the British Rule; the Commission lamented that even after independence this pattern continued. Correlating the general increase in population rate with the number of judges in all cadres, it states that in 1987 India had 15 judges per million populations as against Australia's 41.6 judges, Canada's 75.2, Britain's 50.9 and United States of America's 150. The Commission, therefore, concluded that the total judge strength of 7,675 was grossly inadequate. The Law Commission while conceding that it lacked sound technical analysis opted for the next best thing i.e. opinion of those knowledgeable in the field and the general public opined that the judge strength should be in the ratio of 50 for every million of population. The Apex Court in its verdict in All India Judges Case(2002) has upheld that there should be 50 judges per million. This recommendation has remained on paper. It may incidentally be mentioned that in the High Courts, the sanctioned strength of judges had risen from 421 in 1984 to 811 by March 1992 with 63 vacancies and the sanctioned strength in the High Courts had risen to 950 with 319 vacancies.

It is resolved in the National Conference held in 2013 by the Chief Justice of India with the Chief Justices and Chief Ministers of the respective states that the number of judges shall be increased twice in next five years and see that the number of judges per million is at least 30 and the posts of judges in the subordinate judiciary should be enhanced from 18,000 to 37,000 . The work-load on the judges is differ from one state to another state as the target of disposal of cases is fixed for every judge is 500 but where as it is 120 in the state Madhyapradesh and above 1000 in the state of Orissa. It is held at the Conference that 600 cases are optimum for a senior civil judge and 600 cases for junior civil judge and Metropolitan Magistrate. It is unjust to say that 
to dispose of 500 petty cases on par with criminal offences. Determination of the number of judges required for administration of justice is based on the time taken for trial of the cases in the USA.

The Supreme Court of India has extended the limitation of Fast Track Courts to another five years which are established in accordance with the advices given by the Eleventh Finance Commission. A total of 38.90 lakh cases were made over to the Fast Track Courts for disposal, out of which 32.34 lakhs cases were disposed of by fulfilling the spirit of speedy justice. The Thirteenth Finance Commission had allotted Rs.5,000 crores of budjet allocations to the fast track courts in order to dispose of the backlog cases on war footing. The Law Commission has strongly recommended to the Government of India to commence the process of appointment of judicial officers in the vacancy positions i.e31.4\% of sanctioned posts and also consider the proposal of enhancement of superannuation age from 60 to 62 years and take necessary steps to provide required infrastructure to the courts.

\section{(C) Management Crisis:}

It is obvious from the above statistical information that amongst the many problems that the Justice Delivery System is facing at present, perhaps the most pressing is the nodal problem of swollen dockets. This single problem has given rise to many more, such as inordinate delay for a case to reach hearing; increased reliance on interim orders; inability to attend the equally important administrative matters including docket management; non-availability of lawyers due to concentration of work in the hands of a few, delay breeding vexatious litigation brought in the fond hope of snatching an undeserved interim order and enjoying the fruits thereof for years to come; scaring away of witnesses by frequent adjournments etc., The inability of courts to combat the rise in the number of cases is further compounded by an antiquated mechanism. While the other sectors which too were affected by the post-independence wave of development promptly went in for modernization, the country's judicial system continues to function in the same antiquated manner on account of financial constraints. There is a pressing need to modernize. Docket management is the need of the hour and this is not possible unless we modernize. We have failed to pay sufficient attention to the management aspect because of non-availability of time or failure to comprehend the importance of docket management. Administrative supervision has been limited to problems concerning the judges and the staff but has hardly extended to docket management which single factor has been largely responsible for the present day malaise. Competent judges are not necessarily efficient managers. To improve court management, we must have full time competent managers who would scientifically reassess the case dockets from time to time and ensure that judgetime is put to optimum use. Procedural laws and rules of evidence which are responsible for the high degree of formalization must be suitably altered, simplified and brought in tune with Indian requirements so that they do not consume valuable time, increase the cost of litigation and vex the litigant. Dispensation of justice through law courts is a normative feature of a civilized society. But it must be realized that the members of a civilized society agree to shun violence and have their disputes resolved through an independent and impartial mechanism offered to them, they read in the offer an implied promise that the said mechanism will resolve their disputes within a reasonable time. However, the enormity of pending cases has resulted in a virtual breach of that implied promise. Legal awareness and increased expectation of access to justice is bound to add the strain on our justice delivery system. The inadequacy of the existing justice delivery system has been causing anxieties not only in India but also in highly developed western countries which too are plagued with large scale pendencies. In the absence of an alternative mechanism litigants have no option but to go to court. Broadly speaking litigation can be divided into (1) cases involving substantial question of law and (2) cases in which disputes are factual only. In a poor country like India where the majority of people cannot afford the high cost of litigation, it is essential to provide them with an alternative forum. As such, it is necessary to develop and sustain such programmes and schemes which can supplement the existing system. Exploration of alternatives to the traditional court system as a means of resolving disputes by diverting litigation to non-formal and non-legal for therefore, acquired immense importance. This is all the more necessary in a country like India where prelitigation settlement through conciliation, mediation or arbitration is virtually unknown, unlike in other countries where a large number of cases are resolved amicably before parties go to trial. To some extent it has been possible to achieve this objective by resorting to preventive or strategic Legal-Aid Programmes.

\section{Right To Legal Aid- A Constitutional Mandate:}

The Preamble of the Constitution of India is considered as its conscience. The constitutional edifice rests on its four pillars i.e., (i) Justice (ii) Equality (iii) Liberty (iv) Fraternity. A solemn promise is made to secure to all its citizens Justice- social, economic and political. There can be no equality and no liberty unless the citizens are assured of justice in all its hues. Part III of the Constitution confers certain Fundamental Rights while Part IV thereof outlines the principles for the governance of the country. The fundamental rights conferred on the people would be hallow promises unless there exists a vibrant instrumentality through which they can be enforced in the event of any violation or threatened thereof. Therefore, the Central theme of the Indian 
Constitution is justice, with a view to make the equality clause in the Constitution (Article 14) meaningful. Parliament Article 39A in Part IV of the Constitution containing the Directive Principles of State Policy and this article mandates the right to legal aid as under:

Equal Justice and Free Legal Aid -Article 39A- "The State shall secure that the operation of the legal system promotes justice, on the basis of equal opportunities, and shall in particular provide free legal aid by sustainable legislation or schemes or in any other way, to ensure that opportunities, for securing justice are not denied to any citizen by reason of economic or other disabilities".

To execute the pledge of justice as in the Preamble i.e., socio-economic to provide equal opportunities and to avoid socio-economic imbalances, the Constitution mandates the state to accord justice to all citizens. Social justice is the key note of the constitution, democratic obligation of the state to make the legal process a surer means to social justice. It includes legal justice which means that the system of administration of justice must provide a cheap, expeditious and effective instrument for realization of justice by all section of the people irrespective of their social or economic position. Legal Aid in India has comprehensive constitutional status and being found in the group of articles. The three Golden Articles of the Constitution incorporates the principle of legal aid i.e. article 14, 21 and 22. The principle of equality in article 14 assures equal justice. It guarantees that no person shall be denied equal protection of laws because he is poor, provides accessible to court at free of cost. States he is under a constitutional mandate to provide free legal aid to an accused person who is unable to secure legal services. Justice Bhagavathi extended legal services to the accused by laying down that right to free legal services is an essential ingredient of reasonable fair and justice and it is implicit in guarantee of Art. 21. State cannot avoid it, by pleading financial or administrative liability. Judiciary recognized fair trial including constitutional right of every accused person right to consult and be defended by a legal practitioner of his choice under Art.22. Right to access to justice is a fundamental right and it has been reinforced by 39-A with object to mitigate inequalities so that justice reaches to door steps of the poor and weaker sections of the society. As a part of fair trial procedure, legal aid provisions are dealt under Sec-304 of criminal procedure code.

The idea underlying the insertion of this article was to ensure that no person should, on account of poverty or for lack of means, suffer injustice for the redress of which, a legal remedy is provided. Experience has shown that in all developing countries the poor as a class suffer injustice at the hands of the entrenched and the affluent, the existence of benevolent legislation notwithstanding. It is a matter of general knowledge that the poor are less informed and less knowledgeable in relation to the law. On account of their ignorance and lack of awareness of their legal rights they are less confident, become an easy prey to manipulations and fail to take advantage of the available institutions for fear of a backlash. The legal aid system must, therefore step into infuse a sense of security in them which would embolden them to assert their rights forcefully and effectively.

The Government of India appointed a Committee in 1976 to consider the question of making legal aid and advice available alternatives to the weaker sections of the society and to recommend appropriate action. This Committee recommended submitted its report in 1977 entitled "Report on National Judicature: Equal Justice- Social Justice". This comprehensive document and its recommendations led to the establishment of a High Power Committee called the "Committee for Implementing Legal Aid Schemes" (CILAS) under the chairmanship of a single judge of the Supreme Court of India on $26^{\text {th }}$ September, 1980. This Committee was reconstituted in September1985 with the Chief Justice of India as its patron-in-chief and a single judge of the Supreme Court as its Executive Chairman. The Legal Aid Programmes formulated by this committee are adopted by the State Governments are now providing free legal aid and advice to socially backward classes, women, children, senior citizens, disabled persons and other persons who satisfy the conditions prescribed for admissibility of Free Legal Aid. Today, Free Legal Aid is prevailing to the needy people of the society in all courts in the country, right from the base level courts of Indian Judicial System i.e., Magistrate Courts to the Apex Court of the land. As per the rules contained in the "Legal Services Authorities Act, 1987" which came into force on 9.11.1995, the Legal Services Committees have been functioning at taluk level, district level, state level and high court level.

Persons Eligible for Legal Services under the Act:

\begin{tabular}{|l|}
\hline 1. a member of a Schedules Caste or Scheduled Tribe \\
\hline Tribe \\
\hline The a victim of trafficking in human beings or beggars as referred to in Article 23 of \\
\hline 3. a woman or a child \\
\hline 4. a mentally ill or otherwise disabled person \\
\hline $\begin{array}{l}\text { 5. a person under circumstances of undeserved want such as being a victim of a mass disaster, ethnic violence, caste atrocity, } \\
\text { flood, drought, earthquake or industrial disaster }\end{array}$ \\
\hline 6. an industrial workman; or \\
\hline 7. in custody, including in a protective home \\
\hline within the meaning of clause(g) of section 2 \\
\hline
\end{tabular}




\begin{tabular}{|l|}
\hline of the Immoral Traffic(Prevention) Act, \\
\hline $1956(104$ of 1956$)$; or in a juvenile home \\
\hline within the meaning of clause of section 2 of \\
\hline the Juvenile Justice Act, $1986(53$ of 1986$)$ \\
\hline or in a psychiatric hospital or psychiatric \\
\hline nursing home within the meaning of \\
\hline clause(g) of section 2 of the Mental Health \\
\hline Act, 1987(14 of 1987$)$; or \\
\hline 8. in receipt of annual income less than fifty thousand rupees (Rs.1,00,000/- P.A.). \\
\hline
\end{tabular}

Table: C

What is provided as Legal Service:

\begin{tabular}{|l|}
\hline 1. Help of Advocate at the State Expenses for filling or \\
\hline defending the cases before any Judicial Courts in India, \\
\hline 2. Free legal advice on any matter, \\
\hline 3 By paying the amount of court fee, process fee, fee for \\
\hline drafting of petitions, diet money and other litigation charges, \\
\hline 4 By supplying certified copies of orders, Judgments, Witness etc., \\
\hline 5. By mediation through counseling \& conciliation centre, \\
\hline 6. By way of mediation through the Lok- Adalats \\
\hline
\end{tabular}

Table: D

The legal-aid programme adopted by the Legal Services Authroties and Committees are two-fold in character viz.,(a) court or litigation-oriented legal aid programmes (b) preventive or strategic legal aid programmes. Dispensation of legal aid in respect of litigation-oriented cases is essentially the responsibility of the Legal Services Authorities or Committees set up by the States. These organizations are also charged with the duty to implement the strategic legal aid programmes with the financial assistance extended by the CILAS as and when required. With regard to preventive or strategic legal aid programmes are concerned, the idea is not only to supplement the scheme for assistance in legal proceedings but, where possible to make its use unnecessary by endeavouring to bring about a settlement between the parties by proper counseling at the threshold itself. The CILAS has issued instructions to all the State Level Authorities to put their best efforts to settle disputes at the threshold by bringing the parties to negotiate and only if a settlement cannot be struck to extend legal aid, including financial aid to the party seeking the same, provided a prima-facie case is made out. The underlying object is to combat the problem of docket-explosion by a two-pronged attack namely (i) by checking or curtailing the in-flow of litigation by pre-litigation settlements and (ii) by encouraging settlement of pending cases outside the courts. Consequently legal aid has two elements namely (a) financial aid (b) professional service. A vast majority of the Indians live in abject poverty and ordinarily be denied access to justice on account of penury. The Legal Aid Scheme extends financial assistance to such poverty stricken persons to enable them to assert their rights. They are also provided with qualitative professional service so that the spirit of the 'equality clause' satisfied. Unlike in Britain, members of the legal profession in India, barring junior lawyers, do not receive any payment for the professional service rendered by them. This is because the legal aid system in India is service-oriented. There is a growing feeling that Indians are much too disposed to litigate. This is perhaps on account of want of an alternative. Human ingenuity being limited, it has not been possible to devise an inexpensive and efficient system where disputes could be satisfactorily resolved without court's intervention. The members of the profession play a pivotal role at the very inception of the dispute. They would be able to persuade their clients to negotiate a settlement. If negotiations fail, they can be advised to try for mediation, failing that arbitration, and as a last resort court trial. The opportunity to negotiate missed at the pre-litigation stage is sought to be supplied through the innovative instrumentality of what has come to be known as the 'Lok-Adalath'. Freely translated, lok-adalath means a 'people's court'. A Lok-Adalath differs from a conventional court, in that, it is wholly informal body, shorn of technicalities, where feuding litigants come of their own volition to explore the possibility of setting their dispute. These Lok-adalaths offer an alternative forum to parties to negotiate a settlement. Cases which are considered fit for settlement are identified and placed before Lok-Adalaths after the parties have consented to appear before the Lok-Adalaths. A LokAdalath ordinarily comprises a retired judge/servicing judge, a lawyer and a social worker and each playing the role of a mediator. The informal atmosphere and the total absence of technicality is conductive in order to bring about a settlement. At the end of it, there is no victor and no vanquished and the contesting parties go home as friends. Being a purely voluntary effort, if there is no settlement, the dispute goes back to court for adjudication. By this innovative method, nearly 4,30,41,883 cases (including MACT Cases) have been disposed of at 11,20,232 Lok-Adalaths in about a period of 25 years and a total of 13,557,631 persons benefited in the entire country belonging to SCs, STs, BCs, Women, Children, Acused in Custody and other people up to 31.03.2013 according to Statistical Information released by the National Legal Services Authority. This clearly established 
the fact that Lok-Adalath system in Indian Judicial System as a dispute resolution mechanism has achieved a great success all over the country. The Chief Justice of Australia who has been impressed by the success of this alternative dispute resolution mechanism in India has described it as "the only viable means of disposing of the massive volume of litigation which threatens to mandate the court system".

\section{Procedural Aspects Of Conducting Lok-Adalaths:}

The Lok-Adalaths are generally organized by the State or District legal Services Authorities or Taluk Legal Services Committees. The date and place of holding a Lok-Adalath are fixed about a month or so in advance. The date so fixed is, generally, a Saturday or a Sunday or some other holiday so that normal court work is not disturbed. Information about the holding of a Lok-Adalath is given wide publicity through press, posters and where possible through Radio, Cable Television and Cinema Slides in theatres. Before a LokAdalath is held, its organizers request the presiding officers of various courts to scrutinize cases pending in their respective courts which, in their opinion, are eminently fit for a negotiated settlement. Once the cases are identified, parties to the dispute are motivated by the Para-legal volunteers, retainer lawyers and social workers and by other people connected with these organs to settle their disputes through Lok-Adalaths.

The members of a Lok-Adalath are called conciliators who are usually drawn from amongst servicing or retired judicial officers, social workers and advocates. The number of conciliators is usually three but there is no hard and fast rule. If conciliation results in settlement of a dispute, a 'compromise deed' is drawn up and after obtaining the signatures of the parties to the disputes and their advocates, the compromise deed is presented to the presiding officer of the competent court, who is normally available at the site of the LokAdalath for passing a decree in terms of compromise. Before passing a decree, the judge satisfies himself about the fairness and legality of the compromise and then affixes his seal thereto. Efforts are also made to ensure on the spot payment of compensation, especially in cases involving motor accident claims. Generally in the case of minors, women and illiterate persons, a substantial part of the compensation amount is invested in interest yielding long term fixed deposits to ensure that the same is not frittered away and the claimant receives a steady income. The cases which are generally brought before a Lok-Adalath relate to petty compoundable criminal offences, disputes concerning mutation of land, removal of encroachment on forest lands, matrimonial and other family related disputes, land acquisition disputes, industrial disputes, motor accident claims etc., Further, LokAdalaths also take up all sorts of disputes which have not yet gone to courts.

The necessity and utility of Institution Lok Adalat has been unquestionable because it dispenses speedy and cheap justice to the people and reduces the work load of the regular courts. On the basis of various provisions of the Legal Services Authorities Act, 1987 and the judicial pronouncements made by Apex Court and various High Courts, it is evident that the Lok Adalat system has been established with the object to promote justice on the basis of equal opportunity. In Lok Adalat mechanism there are two kinds of Lok Adalats namely Lok Adalat and Permanent Lok Adalat. The Lok Adalats are organized by various legal services authorities and committees for settling the various matters at different places as per the schedule. A Lok Adalat has jurisdiction to arrive at a compromise between the parties with regard to any matter which may be pending before any court as well as matter which has not yet been formally instituted in any court or tribunal. Such matters may be civil, criminal or revenue in nature, but any matter relating to an offence not compoundable under any law cannot be decided by the Lok Adalat even if the parties involved therein agree to settle such matter. Thus, in a given area, different and separate Lok Adalats can be constituted for dealing with specified types of matters. The cases of matters are referred to Lok Adalat by the Court or by the concerned authority or committee which is organizing the Lok Adalat. The Court refers the pending cases in three ways either (i) on the consent of both the parties, or (ii) at request of one of the parties, or (iii) by court itself. However, it has been discussed above on the basis of judicial decision, that while referring the case or matter the court as well as the authority or committee is bound to follow the prescribed condition under the sub-sections (1) and (2) of Section 20. A Permanent Lok Adalat can be organized for the settlement of disputes at pre-litigation stage, related to public utility services, compoundable criminal offences and the matters where the value of property in dispute does not exceed ten lakh rupees. A dispute may be referred to the Permanent Lok Adalat on the application of any party to dispute and after such application, no party to that application can invoke jurisdiction of any court or a tribunal in the same dispute. It means that such dispute can only, be determined by the PLA. The procedure followed at a Lok Adalat is very simple and shorn of almost all legal formalism and rituals. Every Lok Adalat or Permanent Lok Adalat is free to formulate its own procedure for the purpose of conducting conciliation. Lok Adalats attempt to resolve the dispute by helping the parties to arrive at an amicable settlement and if the parties fail to settle the dispute, then the case is either returned to courts of law or the parties are advised to seek remedy in a court of law. It means if no compromise or settlement is or can be arrived at, no order can be passed by the Lok Adalat because it has no adjudicatory power to decide the cases. While, if disputes are not settled by Permanent Lok Adalat by the way of conciliation, then the disputes can be decided on the basis of merit. Because, it has been revealed that PLA under Section $22 \mathrm{C}(8)$ can exercise its decision making power for the 
determination of the dispute. But, when the Permanent Lok Adalat disposes of the case on the failure of conciliation proceeding, a sufficient opportunity must be granted to the parties so that they may address the Adalat on their respective plea. As it has been directed by the Supreme Court and various High Courts that such power must be used with due care and caution and invoked only as a last resort. The Lok Adalats or Permanent Lok Adalats shall be guided by the principles of natural justice, objectivity, fair play, equity and other principles of justice without being bound by the Code of Civil Procedure and the Indian Evidence Act. The expression 'the other legal principles' also include the judgement of the Apex Court as well as High Courts in regard to any case or matter referred to Lok Adalat for settlement. As per the directions of the Court, they are also obliged to follow the statutory provisions, rules and regulations made under the Act, 1987. It has been conferred with all the indicia of a court since it shall be deemed to be a civil court. So, it enjoys the same powers as that of a civil court in summoning and enforcing the attendance of any witness; examining him on oath; reception of evidence on affidavits; requisition of any public record or document. Every award of Lok Adalat or Permanent Lok Adalat shall be final and binding on all the parties to the dispute and shall be deemed to be the decree of civil court. The award of Lok Adalat is an order by the Lok Adalat with the consent of the parties, instead of the process of arguments in court, therefore, there is no need either to reconsider or review the matter again and again, and no appeal can be filed against the award. But such award of Lok Adalat and/or PLA come under the writ jurisdictions of the High Court and the Supreme Court only when the award has been passed against the statutory provisions and principle of natural justice. It is necessary to provide this opportunity to aggrieved party against the miscarriage of justice by Lok Adalat or Permanent Lok Adalat. Therefore, the Lok Adalat system due its functioning has been famous for delivering informal, cheap and expeditious justice to the common man. So, it is necessary to further the scope of the system by establishing separate Lok Adalats for the government departments and public sector undertakings and by bringing more matters under the jurisdiction of Lok Adalat like intellectual property rights, environment, matters relating to education system, money laundering, cyber crime, taxation, banking services, services by professionals and business matters, etc. Similarly, Lok Adalat should be empowered to decide the cases on the basis of merit as the PLA can decide. It is submitted that these suggestions may improve the structure, working, procedure and result of the functioning of the Lok Adalat system in the present scenario.

\section{Success Of Lok-Adalath System- A View:}

Let us mention a few instances to show the success of Lok-Adalaths. Over11,20,232 Lok-Adalaths have been organized so far in various parts of the country at which about4,30,41,883 cases have been settled, including 21,04,817 cases of motor accident claims wherein compensation amounting to over Rs.115,821,527,600/- disbursed to the claimants up to 31.03 .2013 as per the report and Statistical Data published by the National Legal Services Authority. Lok-Adalaths have also been successful in settling the cases of a large number of persons affected on account of acquisition of their lands for public purposes. In one Lok-Adalath at Vizag, claims for additional compensation of about 25,000 villagers whose lands were acquired for a steel plant were settled. Similarly about 40,000 land acquisition cases arising out of three irrigation projects were settled in the state of Andhrapradeh. Claims of 9046 small cane growers and 1186 workmen of sick sugar factories taken over by the State Government were settled at a single Lo-Adalath and payment to the tune of Rs.12.33 million was made. The success rate in disputes relating to motor accident claims, revenue matters and minor criminal matters has been quite hearing. However, in family and matrimonial disputes the success rate has not been significant. Because such cases are generally time-consuming and cannot be resolved on a single day. To overcome this situation, the experiment of settling such cases through Family Counseling Centers has been undertaken and the response is fairly encouraging. Recent attempts to settle Bank-loans, Telephone bill arrears cases through Lok-Adalaths has proved successful and the pressure for holding Lok-Adalaths for such cases is increasing. The skepticism which was in evidence among various sections of the people at the initial stage is gradually giving way to acceptance of the efficacy of this informal system. In fact there is a demand from certain quarters for institutionalizing the Lok-Adalaths. In the light of the experience gained so far in organizing Lok-Adalaths, it is now proposed to clothe them with more powers with a view to improve their efficacy. For this purpose, the Legal Services Authorities Act, 1987 has been enacted which came into force on 9.11.1995 with a view to satisfying the constitutional obligation of Article 39A which provides for setting up of Authorities at the State levels to be monitored by the National Legal Services Authority at the centre. These Authorities are obligated to formulate the policies and principles and frame economical schemes for providing legal services to the poor and the needy, to initiate public interest litigation concerning the rights of members of the weaker segments of the society, to give training to social workers in legal skills, organize legal-aid camps to educate the weaker sections of the society as to their rights, encourage settlement of disputes through LokAdalaths and generally ensure access to justice. Under the new legislation Lok-Adalaths are vested with the powers of a Civil Court in respect of the summoning of witnesses, discovery and production of documents, calling of public records, reception of evidence on affidavits. Apart from conducting Lok-Adalaths, Legal 
Services Authorities or Committees as the case may be are organizing 'Legal Awareness Camps' specially in rural areas in order to inculcate the legal knowledge and to provide a forum through which people living in rural or tribal areas could obtain competent legal aid or advice at their door-steps for resolution of their disputes.

\section{Merits And Demerits Of Lok-Adalath System In Indian Judiciary:}

The concept of justice is largely dependent on socio-cultural heritages. The conscience of the Constitution, which echos the aims and aspirations of the people, speaks through its Preamble. But the concept of social justice, like all other abstract concepts, is an eluding one, not capable of precise definition, not even a broad formulation. The quest for identifying the ideals of social justice began on our attaining independence and the pursuit is still on. Several reformative legislations were enacted to benefit the poor and umpteen number of poverty amelioration schemes have been introduced from time to time to combat poverty but, alas, the benefits of these legislations and schemes have not reached the poor on account of defective implementation, indifference, prolonged litigations etc., In an economic system like ours there is a related need for professional support to ensure effective implementation of such laws and schemes. It is here that we see lack of sufficient professional service support to that vast majority who cannot afford competent professional service. It is our endeavour to bridge this gap through our legal aid programmes.

This philosophy of legal aid as enshrined in Article 39A of the Constitution has many facets which can be described as a) financial b) curative c) educational d) preventive e)service-oriented etc., In this present paper I propose to highlight certain aspects of legal aid, viz., (i) the Lok-Adalath Movement (ii)PreLitigation Conciliation and (iii) Training Para-Legal Volunteers to serve the illiterates who are unaware of their legal rights and obligations. The idea of disposal of cases through lok adalaths was first mooted in March, 1982 when the country's first lok-adalath was held at Una. The experiment caught up and spread throughout the country. Since by now over 6000 Lok-Adalaths have been held throughout the length and breadth of our country; the time is ripe for taking stock of the situation and identifying the shortcomings ,if any, and finding solutions to overcome or remove them. Next I propose to focus more intensively on Pre-Litigation Conciliations. At present, in the absence of an alternative forum, all disputes are required to be carried to courts for adjudication. In other countries the emphasis is shifting to have disputes settled through negotiations, mediation and if necessary arbitration. Unfortunately, the cost of proceedings before the arbitrators has risen sharply and that mode of settlement is fast becoming virtually beyond the reach of the common man. We have therefore, to depend more and more on negotiation, conciliation and mediation. Unless we settle the cases at the threshold level, through negotiations, etc., we will not be able to check the in-flow of the cases to courts. If we are not be able to ensure that cases which do not involve any substantial question of law are settled outside the Court-rooms we will not be able to assist the legal system in deciding cases taken to court within a reasonable time. To achieve this objective, it may be necessary to set-up conciliation and counseling cells at taluk and district levels. Here we seek the assistance of the members of the profession. If the members of the profession are service oriented and endeavour to settle the disputes while the same are still in their chambers a good number of cases may not require adjudication by Courts. Roscoe Pound rightly described professionals as "a group persuing a learned art a common calling in the spirit of public service". Edmund Pallegrino, Director of Kennedy Institute of Ethics was more forthright when he differentiated members of the profession from businessmen by emphasizing "at some point in professional relationship, when a difficult decision has to be made, you can depend on the one who is in a true profession to efface his own self-interest". The legal profession being the custodian of legal knowledge and information is, therefore, expected to play a dynamic role to discharge its obligation to society. The privilege to practice law and to be member of the noble profession carries with it the obligation to place service to society above self-interest. Therefore, if members of the profession realize this obligation to society and try to resolve disputes at the threshold levels of in their chambers rather than push them in courts, they will render a great social service which will go a long way in helping retain people's confidence in the system.

One of the main contributions to the litigation docket is the Government. The Civil Procedure Code, 1908, Section 80 provides for a notice of two months before a suit is filed against the Government. The underlying idea was to give the Government time to examine the claim of the proposed plaintiff and if found to be correct to settle it at the threshold. It is common knowledge, not a single litigation is settled during the said period. Besides the Government is not known to avoid filing and contesting untenable causes. Certain State Governments have taken policy decisions to file an appeal even in the Apex Court in certain category of cases regardless of merit. All this generates a large volume of avoidable litigation. Next the Central and State Governments do not come forward to settle their cases through Lok-Adalaths for one reason or the other. This creates a somewhat paradoxical situation since the State Legal Services Authorities or Mandal or Taluk Legal Services Committees are financed by the State Governments. It is at times embarrassing when questioned why the Government does not show confidence in a system it is financing. When Insurance Companies and now even Banking Institutions are coming forward to settle their cases, it is difficult to understand the reluctance of 
the Governments. The State Government of Andhrapradesh, has, however shown the lead in this behalf. Due to its positive and programmatic approach over ten thousand claims of employees and small cane growers of two defunct sugar factories taken over by the State Government were settled. Similarly, nearly 50,000 land Acquisition Cases arising from three projects have been settled. In addition there to several Land Acquisition Cases were settled at Karimnagar and Visakapatnam districts in Andhrapradesh state. A little initiative and a williongness to negotiate can put an end to the misery of many. A little extra effort to persuade their respective State Governments to take a positive approach in the matter of resolving the cases through Lok-Adalaths by the State Legal Services Authorities is the need of the hour. In the same manner, the respective cabinet ministers shall persuade their good offices to settle cases, identified as fit for settlement, through Lok-Adalaths. By doing so those who man the state instrumentalities will be able to fulfill their political pledge and national tryst to meet the Constitutional objective of rendering justice, social, economic, and political to the people of this great and largest democracy.

The third aspect in the concept of free legal aid is training of Para-legal volunteers to help our poor and ignorant masses. Great care must; however, be taken in the choice of personnel for such training. In the first place, we must be assured that those chosen have the basic education for understanding and assimilating the elementary knowledge about the laws in regard to which they are imparted training. Secondly, we must ensure that they are service-oriented and have roots in the areas where they are expected to operate. It is no use training those who have no roots or likely to leave the area or zone in search of pursuits elsewhere. Thirdly, we should take care in picking up only those laws for training which are likely to prove useful in that area. Fourthly, they must be provided sufficient incentive and status in the society for the services rendered by them. If, keeping the above in mind, we identify areas or zones where such Para-legal volunteers, trained not only in basic laws but also in the art of negotiating settlements, are put into service they will be able to render useful service to our poor and underprivileged citizens and help to avoid unnecessary disputes and strifes. In Pre-Litigation Centers in the state of Gujarat have been set up since quite some time and they are functioning quite well. In Delhi we have setup Family Counseling Centers and they too are doing good work.

\section{Conclusion:}

Indian law cannot afford to be out of tune with the Constitutional objective of socio-economic justice. Where the vast majority of the people are backward, both educationally and economically, and where the society is full of inequalities based on the caste system, the national goal of socio-economic justice based on the laudable concept of equality is not easy to achieve unless we have a vibrant scheme to take justice to the doorsteps of those who are, because of their socio-economic handicaps, unable to reach the door-steps of the court. Either the conciliator must go to the mountain or the mountain must come to the conciliator, for otherwise there will be a stalemate and the Constitutional conveyance carrying the mission of socio-economic justice will grind to a halt. The law and its instrumentalities must provide the required motive power to carry the conveyance to its ultimate destination and realize the dream of equality before the laws and more particularly the equal protection of the laws. To reach out to those consumers of justice who cannot reach the instrumentalities of justice on account of penury, illiteracy and social suppression of centuries. Let us all join hands and resolve this day to translate the majestic concept of equality and fulfill the Constitutional objective of social justice to all through the instrumentality of the Legal Aid and advice programmes by making the thrust thereof more intensive and extensive.

The hall-mark of a welfare state governed by the rule of law is that it assures access to justice to the common man. Every effort must be made to make justice inexpensive so as to make it available to the poor as well. The Constitutional promise of social justice cannot be kept unless we make a three prolonged attack to (i) eliminate ignorance and lack of awareness of legal rights, (ii) counter economic imbalance and its fall out and (iii) ensure resolution of a dispute within a reasonable time. In a over-populated and geographically vast country like India, the majority of whose people are poor and live in villages, statutory and constitutional rights and guarantees would be meaningless, if access to justice is difficult and prohibitive. The only way in which easy access to justice can be provided to them is by developing an alternative which would carry justice to their door steps. This has been possible through Lok-adalaths and Para Legal and Legal Literacy Camps which offer an informal system for on the spot resolution of disputes, prevent disruption of local unity and secure social justice which is in tune with the life style and culture of village-folk. Justice rendered at such lok-adalaths in the presence and hearing of others from the locality or village is more satisfying and nearer to the truth. With the heavy case-load in the traditional courts and time consuming process through which litigation must pass, looking for alternative modes for disposal of cases is compelling necessary. 


\section{Bibliography}

[1]. Agarwal Nomita, Hand Book on Lok Adalath in India, New Delhi: Interest Publications, 1991

[2]. Ahmed, Ezas, The Code of Criminal Procedure, 1973, Allahabad: Ashoka Law House, 1984

[3]. Anurag Agarwal,K. Role of Methods in Development of Society: Lok Adalth in India, Ahmedabad: Indian Institute of Management, 2005

[4]. Avad Prasad, Lok Adalath, New Delhi: Sterling Publishers Pvt Ltd., 1978

[5]. Baxi Upendra, and Justice V.R. Krishna Iyer, Social Justice- Sunset or Dawn, Lucknow: Eastern Book Company, 1998

[6]. Bhargava Prabha, Lok Adalath (Justice at the Doorsteps), Jaipur: INA Shree Publishers, 1998

[7]. Basu Durga Das, Introduction to the Constitution of India, New Delhi: Prentice Hall of India Pvt. Ltd., 1991

[8]. Cappelleti, Towards Equal Justice: A Comparative Study of Legal Aid in Modern Societies, Milano Oceana Publications, 1975

[9]. Chaturvedi, Rights of Acused under The Indian Constitution, New Delhi: Deep and Deep Publications, 1976

[10]. Dhavan Rajeev, Litigation Explosion in India- Genesis and Functioning, New Delhi: Deep and Deep Publishers, 1986

[11]. Misra B.B., The Judicial Administration of the East India Company in Bengal (1762-82), Oxford: Oxford University Press, 1961

[12]. Narayana P.S., Law Relating to Lok Adalaths, Hyderabad: Asia Law House, Hyderabad: 2001

[13]. Swroop, R., Law Relating to Legal Aid and Lok Adalaths. Hyderabad: AID Publications

[14]. Thakwani, C. K., Civil Procedure Code, Lucknow: Law Publications, 1987

[15]. Verma, B.L., Development if Indian Legal System, New Delhi: Deep \&Deep Publications, 1987

[16]. Law Commission Reports, Acts, Rules and Government Orders and Circulars

[17]. Journals and Periodicals and News Dailies 